\title{
Development of Companies in Modern Conditions of Economic and Legal Relations
}

\author{
Bohdana Baida ${ }^{1}$, Lesya Khomko ${ }^{2}$, Oksana Levytska ${ }^{3}$ \\ ${ }^{1}$ Lesia Ukrainka East European University, Lutsk, Ukraine \\ ${ }^{2}$ Lviv State University of Internal Affaries, Lviv, Ukraine \\ ${ }^{3}$ Lviv Polytechnic National University, Lviv, Ukraine
}

\begin{abstract}
This paper proposes a methodology approach that provides the solution to practical problems of companies in case of the innovation implementation in modern conditions of the economic and legal relations. The approach makes it possible to evaluate a strategy for the innovative development considering components, such as the integral indicator of a company's innovation activities, an integral indicator of innovative capability of a company.
\end{abstract}

Keywords - Strategy, Evaluation, Integral indicator, Innovation activities, Innovative capability.

\section{Introduction}

The key political event in 2016 was the signature of the EU-Ukraine Association Agreement. This situation challenged the economists to broaden scientifically support to the implementation of the Agreement in domestic legal and institutional framework, and to the introduction of new rules and management decisions [2]. This leads to a change of conditions for the development of economic and legal relations, deepening cooperation between Ukraine and the EU and international institutions. Improvement of business management and the development of innovative strategies are therefore critical for countries and enterprises.

DOI: $10.18421 /$ TEM92-29

https://doi.org/10.18421/TEM92-29

Corresponding author: Bohdana Baida, Lesia Ukrainka East European University. Email: bb12345@i.ua

Received: 20 January 2020.

Revised: 18 March 2020.

Accepted: 25 March 2020.

Published: 27 May 2020.

(cc) BY-NC-ND@ 2020 Bohdana Baida, Lesya Khomko \& Oksana Levytska; published by UIKTEN. This work is licensed under the Creative Commons AttributionNonCommercial-NoDerivs 3.0 License.

The article is published with Open Access at www.temjournal.com
Our country is experiencing difficulties in the creation of a policy in order to motivate innovation enterprises and legal protection research. Further adapting Ukraine's domestic legislation and developing the legislative basis regulating the rights for the intellectual property's objects to Council of Europe standards is a priority.

Until recently, most of the economic relations in different branches of the economy were adjusted by a hand-operated control. Therefore, a number of companies and governments actively adhere to a preponderant focus on an innovative development.

Today the Ukrainian enterprise has a unique opportunity to cooperate with international organizations and other intergovernmental institutions and attract foreign investors. That situation, together with globalization and the new economic practices in EU countries, reflected many factors affecting the actual implementation of the rights and obligations of parties to economics, legal relations and ensuring compliance with the provisions and regulations set out in the legislation. Recent trends in the development of a clear innovative development strategy, transparency of pricing; resource efficiency, environmental and energy security are considered in strategic planning and programming.

In the concept of innovative development there are two important elements, namely the question of forming and choosing an effective strategy for innovative development of companies, and assessment of the level of innovative development [16]. The dominance of the theory of innovative development in current economic conditions diversifies the directions of the functioning of companies, highlighting innovative activity as a priority [12]. Under the influence of the sustainability of the modern economy and public policies, there is a need to ensure the effective development and functioning of companies based on innovative principles [5], [7], [11].

Because of current economic conditions, forming and assessment of a strategy for innovative development is high on the list of company's policy priorities for countries in transition [23]. Therefore, in the period of contemporary transformations of the Ukrainian economy, the issues of efficient and effective 
innovation management of the companies, and assessment of a strategy for innovative development, identifying the current state of innovation, making recommendations for improving innovation development are very important for the Ukrainian companies. Only through an effective strategy for innovative development could the enterprises realize the strategic objectives that it had set for itself.

Given these conditions, it is evident that there is no one-approach-fits-all solution with regard to the formation and selection of strategies for the innovative development of organizations. There is a wide range of factors that are related to strategies for innovative development. Only a small number of factors are still considering when choosing the company's strategy.

Therefore, the design of the adequate strategy for innovative development and the strengthening of the competitiveness of national enterprises are the key for success of these initiatives.

In order to affect high quality of the papers, the authors are requested to follow instructions given in this sample paper. Regular length of the papers is 5 to 12 pages.

\section{Methods}

The proposed approach makes it possible to evaluate a strategy for innovative development of companies take into account the components, such as an integral indicator of the company's innovation activities, the integral indicator of innovative capability of the company. Expert method for determining the weight of indicators has been used. This approach is based on the construction of the scale of choice of strategy for the company's innovative development and allows identifying nine strategies. Matrix method has been used in our research to determine the scale of choice of strategy for the company's innovative development, relationship between the quantitative values of the Harrington scale and the direction of the company's innovative development. All aspects of innovative development of the company are adequately covered in these types and elements of the strategy. The elements of the cognitive and linguistic study have been used in concluding the direction of the company's innovative development.

\section{Results}

The innovation activity of the company is the degree of effective use of resources involved in the innovation process of a company. Innovation activity of the company can purchase, creation, the realization of innovations in various spheres of the company's activity. The extent to which managerial influences, functions, resources, and skills are utilized is criterion of innovation activity in a company.

The level of innovative activity of the company should be estimated by the following groups: innovation expenditure, innovation outcomes, and the pace of innovation. The proposed methodology for assessing the level of innovation activity is shown in Figure 1.

\begin{tabular}{|c|c|c|}
\hline \multicolumn{3}{|c|}{ Indicators } \\
\hline $\begin{array}{l}\text { Innovation } \\
\text { expenditure }\end{array}$ & $\begin{array}{l}\text { Innovation } \\
\text { outcomes }\end{array}$ & $\begin{array}{c}\text { Pace of } \\
\text { innovation }\end{array}$ \\
\hline $\begin{array}{c}\mathrm{R} \& \mathrm{D} \text { cost } \\
\left(C_{\left.R D^{/} C_{R D 0}\right),}\right. \\
C_{R D 0^{-}} \\
\text {indicator with } \\
\text { base period }\end{array}$ & $\begin{array}{c}\text { Number of new } \\
\text { technologies or } \\
\text { product } \\
\left(N_{T P} / N_{T P 0}\right), \\
N_{T P 0}- \\
\text { indicator with } \\
\text { base period. }\end{array}$ & $\begin{array}{c}\text { Average duration } \\
\text { of the R\&D process } \\
\left(D_{R D} / D_{R D 0}\right) \\
D_{R D 0} \text { - indicator } \\
\text { with base period }\end{array}$ \\
\hline $\begin{array}{c}\text { Costs for } \\
\text { introduction of } \\
\text { innovations } \\
\left(C_{I} / C_{I 0}\right), \\
C_{I 0} \text { - indicator } \\
\text { with base } \\
\text { period }\end{array}$ & $\begin{array}{c}\text { Number of } \\
\text { innovations } \\
\text { introduced } \\
\left(N_{I} / N_{I 0}\right), \\
N_{I 0} \text { - indicator } \\
\text { with base period }\end{array}$ & $\begin{array}{c}\text { Average duration } \\
\text { of introduction of } \\
\text { innovations } \\
\left(D_{I} / D_{I 0}\right) \\
D_{I 0} \text { - indicator } \\
\text { with base period }\end{array}$ \\
\hline $\begin{array}{c}\text { Costs for } \\
\text { production of } \\
\text { innovations } \\
\left(C_{P} / C_{P 0}\right) \text {, } \\
C_{P 0}- \\
\text { indicator with } \\
\text { base period }\end{array}$ & $\begin{array}{c}\begin{array}{c}\text { Number of } \\
\text { innovations } \\
\text { produced }\end{array} \\
\left(N_{P} / N_{P 0}\right), \\
N_{P 0} \text { - indicator } \\
\text { with base period }\end{array}$ & $\begin{array}{c}\text { Average duration } \\
\text { production of } \\
\text { innovations } \\
\left(D_{P} / D_{P 0}\right), \\
D_{P 0}-\text { indicator } \\
\text { with base period }\end{array}$ \\
\hline $\begin{array}{c}\text { Distribution } \\
\text { costs } \\
\left(C_{M} / C_{M 0}\right) \\
C_{M 0}- \\
\text { indicator with } \\
\text { base period }\end{array}$ & $\begin{array}{c}\text { Quantity of sold } \\
\text { innovations } \\
\left(N_{C I} / N_{C I 0}\right), \\
N_{C I 0^{-}} \\
\text {indicator with } \\
\text { base period }\end{array}$ & $\begin{array}{c}\text { Average duration } \\
\text { of delivery of } \\
\text { innovations to the } \\
\text { market } \\
\left(D_{M} / D_{M 0}\right) \\
D_{M 0} \text { - indicator } \\
\text { with base period }\end{array}$ \\
\hline $\begin{array}{c}\text { Cost of } \\
\text { protection of } \\
\text { intellectual } \\
\text { property } \\
\left(C_{P P} / C_{P P 0}\right), \\
C_{P P 0}- \\
\text { indicator with } \\
\text { base period }\end{array}$ & $\begin{array}{c}\text { Number of } \\
\text { patents obtained } \\
\left(N_{P P} / N_{P P 0}\right), \\
N_{P P 0}- \\
\text { indicator with } \\
\text { base period }\end{array}$ & $\begin{array}{c}\text { Average timeframe } \\
\text { to obtain a patents } \\
\left(D_{P P} / D_{P P 0}\right) \\
D_{P P 0} \text { - indicator } \\
\text { with base period }\end{array}$ \\
\hline
\end{tabular}

Figure 1. Methodology for assessing the level of innovation activity

Source: Formed according to [9], [5]

The calculation of the level of innovation activity of the company is proposed to be calculated on the basis of indicator values of innovation activity, and 
to compare them with the indicator values of the baseline period or to compare with the degree of deviation of the indicator values from threshold values.

An assessment of the level of innovative activity of the company can be carried out by the expert method. The expert group can consist of leading management experts from a broad range of fields aimed at financial, economic, human resources, marketing, scientific and technical ways. The scoring method from 1 to 10 for evaluating indicators, approved experts should be used.

Integral indicator of the level of innovation activity $\left(I_{I A}\right)$ will be calculated as follows [22]:

$$
I_{I A}=\sum_{l=1}^{n} \frac{\sum_{j=1}^{m} W_{l j}}{m} * d_{l},
$$

$W_{l j}$ - the value $j$ indicator of $l$ group;

$d_{l}$ - the degree of influence of $l$ group on the overall level of innovation activity (the weight of indicators); $m$ - the number of evaluation indicators for each group;

$n$ - the number of groups.

To interpret the results of innovation activity calculation we have developed a rating scale of innovation activity levels (Table 1). A five-step criteria system as the basis for evaluation was used [6].

Table 1. The scale of evaluation of values of innovation activity levels

\begin{tabular}{|c|c|}
\hline $\begin{array}{c}\text { Qualitative assessment of } \\
\text { innovation activity levels }\end{array}$ & $\begin{array}{c}\text { Quantitative values of } \\
\text { innovation activity levels }\end{array}$ \\
\hline High & $(0,8-1]$ \\
\hline Above average & $(0,63-0,8]$ \\
\hline Average & $(0,37-0,63]$ \\
\hline Below average & $(0,2-0,37]$ \\
\hline Low & {$[0-0,2]$} \\
\hline
\end{tabular}

Source: [6]

Another important component of the strategy for the company's innovative development is an effective assessment of the level of innovative capability [20].

Innovative capability is the degree of ability and preparedness of a company to innovation activity. Therefore, the components (production and technological capability, company staff, investments, scientific and technical capability, management, marketing, and innovative projects risk) are essential for measuring the level of innovative capability.

The system of indicators for assessing the level of innovative capability of the company (Figure 2) was proposed by the systematization of indicators presented in the works [9], [21], [16]. The factors that are the motivators are taken into account in the study.

\section{The main components}

Production and technological capability:

1) coefficient of equipment progressivity at the reporting date compared to the base year, $K_{e c}$, $K_{e c 0}$ - indicator with base period,

2) coefficient of equipment modernization at the reporting date compared to the base year, $K_{e m}$,

$K_{e m 0}$ - indicator with base period,

3) number of innovative measures aimed at reinforcing the effectiveness of production at the reporting date compared to the base year, $K_{i n}, K_{i n 0}$-indicator with base period,

4) deterioration factor, $F$

Company staff:

1) number of persons employed in innovative projects at the reporting date compared to the base year, $S_{e}$ , $S_{e 0}$ - indicator with base period,

2) number of scientific and technical professionals to total staff employed in innovative projects at the reporting date compared to the base year, $S_{s t}$, $S_{s t 0}$ - indicator with base period,

3) employees' qualification coefficient concerning the complexity of the work (a measure of the average tariff category of the employees and the average tariff category of work performed) compared to the base year, $S_{e c}, S_{e c 0}$ - indicator with base period,

4) employees stability index (a measure of the number of employees with work experience in an organization for more than one year and an average number of employees) compared to the base year,

$S_{e s}, S_{e s 0}$ - indicator with base period

Investments:

1) development cost of the project at the reporting date compared to the base year, $I_{d p}, I_{d p 0}$ indicator with base period,

2) costs for the implementation of the project at the reporting date compared to the base year, $I_{i p}$,

$I_{i p 0}$ - indicator with base period

3) production sales revenue at the reporting date compared to the base year, $I_{p s}, I_{p s} 0$ - indicator with base period,

4) liquidity ratio compared to the standard value, $R_{l}$ (normative value 2),

5) financial autonomy ratio compared to the standard value, $R_{a}$ (normative value 0,5 ),

6) return on assets, compared to the deposit rate $(F D)$, $R O A$

Scientific and technical capability:

1) number of service lines at which $R \& D$ are done compared to the base year, $C A_{s l}, C A_{s l 0}$ indicator with base period,

2) share of manufactured innovative products in 
output compared to the base year, $C A_{\text {mip }}$,

$C A_{\text {mip } 0}$ - indicator with base period

\section{Marketing:}

1) product sales volume in value terms compared to the base year, $V_{p s}, V_{p s} 0^{-}$indicator with base period,

2) cost efficiency index (a measure of the product sales volume and the amount of advertising costs) compared to the base year, $C E I, C E I_{0}$ indicator with base period,

3) profitability of sales compared to the base year, $P S, P s_{0}$ - indicator with base period

Innovative projects risk:

1) risk of delay in the creation of projects (a measure of the number of projects created on time and the number of projects created) compared to the base year, $R c p, R c p_{0}$ - indicator with base period,

2) project implementation risk (a measure of the number of projects completed and a total number of projects) compared to the base year, $R p i$,

$R p i_{0}$ - indicator with base period

Management:

1) efficiency of management (a measure of the profits and management costs) compared to the base year, $M_{e}, M_{e 0}$ - indicator with base period,

2) number of management employees (a measure of the number of executive personnel and total number of employees) compared to the base year $M_{n e}, M_{n e 0}$ - indicator with base period,

3) efficiency of management costs (a measure of the number or volume of sales and management costs) compared to the base year, $M_{c e}, M_{c e 0}$ indicator with base period

Figure 2. Methodology for assessing the level of innovative capability

Source: Formed by authors based on [4], [9], [16]

Integral indicator of the level of innovative capability $\left(I_{I C}\right)$ will be calculated as follows [24]:

$$
I_{I C}=\sum_{l=1}^{n} \frac{\sum_{j=1}^{m} F_{l j}}{m} * q_{l},
$$

$F_{l j}$ - the value $j$ indicator of $l$ group;

$q_{l}$ - the degree of influence of $l$ group on the overall level of innovative capability (the weight of indicators);

$m$ - the number of evaluation indicators for each group;

$n$ - the number of groups.

To interpret the results of innovative capability calculation we have developed a rating scale of innovative capability levels (Table 2). A five-step criteria system as the basis for evaluation was used [6].

Table 2. The scale of evaluation of values of innovative capability levels

\begin{tabular}{|l|c|}
\hline $\begin{array}{c}\text { Qualitative assessment of } \\
\text { innovative capability } \\
\text { levels }\end{array}$ & $\begin{array}{c}\text { Quantitative values of } \\
\text { innovative capability } \\
\text { levels }\end{array}$ \\
\hline High & $(0,8-1]$ \\
\hline Above average & $(0,63-0,8]$ \\
\hline Average & $(0,37-0,63]$ \\
\hline Below average & $(0,2-0,37]$ \\
\hline Low & {$[0-0,2]$} \\
\hline
\end{tabular}

Source: [6]

The benefits to the business of innovation can be considerable, but can be a great risk of company innovative activities too [10], [13]. The practical need to identify the risks of the company is longer and a matter of urgency [15], [18].

The strategies for company's innovative development include the following types: initiative alternator strategy; initiative pioneer strategy; initiative imitator strategy; initiative and inert strategy of the pioneer; initiative and inert strategy of the imitator; inert imitator strategy; initiative conservator strategy; initiative and inert conservator strategy; inert conservator strategy.

The choice of strategy for the company's innovative development depends on the results of all integrated indicators: the level of innovation activity, the level of innovation capability, the level of risks of innovation activity. The scale of choice within a strategy for the company's innovative development, is developed on the basis of scientific works [5], [9] and are shown in Figure 3.

\begin{tabular}{|c|c|c|}
\hline $\begin{array}{c}\text { Initiative } \\
\text { alternator strategy } \\
I_{I A} \rightarrow \max \max \end{array}$ & $\begin{array}{c}\text { Initiative pioneer } \\
\text { strategy }\end{array}$ & $\begin{array}{c}\text { Initiative and } \\
\text { inert strategy of } \\
\text { the pioneer }\end{array}$ \\
$I_{I C} \rightarrow \max \max$ & $I_{I C} \rightarrow \max$ & $I_{I A} \rightarrow \min \max$ \\
& & $I_{I C} \rightarrow \max$ \\
\hline Initiative imitator & Initiative and & Inert imitator \\
strategy & inert strategy of & strategy \\
$I_{I A} \rightarrow \min \max$ & the imitator & $I_{I A} \rightarrow \min$ \\
$I_{I C} \rightarrow \min \max$ & $I_{I A} \rightarrow$ max min & $I_{I C} \rightarrow \min$ \\
& $I_{I C} \rightarrow$ max min & \\
\hline Initiative & Initiative and & Inert conservator \\
conservator & inert conservator & strategy \\
strategy & strategy & $I_{I A}=0$ \\
$I_{I A} \rightarrow \min$ & $I_{I A} \rightarrow 0$ & $I_{I C}=0$ \\
$I_{I C} \rightarrow 0$ & $I_{I C} \rightarrow 0$ & \\
\hline
\end{tabular}

Figure 3. The scale of choice of strategy for company's innovative development

Source: Formed by authors based on [5], [9] 
Types and characteristics of strategy for company's innovative development [3], [19] are shown in the Table 3.

Table 3. Types and characteristics of strategy for the company's innovative development

\begin{tabular}{|l|l|}
\hline Types & \multicolumn{1}{c|}{ Characteristics } \\
\hline & $\begin{array}{l}\text { The strategy envisages the development of the } \\
\text { company due to qualitative changes in the } \\
\text { elements of the innovation process and } \\
\text { maximum utilization of the existing } \\
\text { capabilities. The strategy has a significant }\end{array}$ \\
impact on the production process. This is \\
accompanied by the formation of \\
organizational structures, the creation of \\
completely new ideas, models, technologies, \\
products. The strategy is focused on \\
maximizing the motivation for the generation \\
in overcoming current challenges, creation of \\
innovations, support, implementation, transfer, \\
and marketing of innovations.
\end{tabular}

\begin{tabular}{|c|c|}
\hline 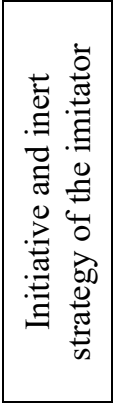 & $\begin{array}{l}\text { The strategy envisages the development of the } \\
\text { company due to quantitative and qualitative } \\
\text { changes in the elements of the innovation } \\
\text { process. There is not always an impact on the } \\
\text { production process and organizational } \\
\text { structure. The strategy is focused on imitating } \\
\text { existing innovations, purchasing patents and } \\
\text { licenses. The strategy provides a stable level of } \\
\text { innovation activity with efficient use of } \\
\text { innovation capability. }\end{array}$ \\
\hline 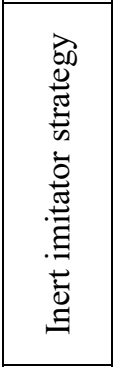 & $\begin{array}{l}\text { The strategy envisages the development of the } \\
\text { company due to quantitative changes in the } \\
\text { elements of the innovation process. There is } \\
\text { not always an impact on the production process } \\
\text { and organizational structure. The strategy is } \\
\text { focused on imitating existing innovations, } \\
\text { purchasing patents and licenses. The strategy } \\
\text { provides a minimum level of innovation } \\
\text { activity with the use of innovation capability. }\end{array}$ \\
\hline 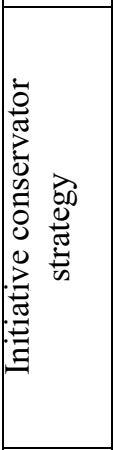 & $\begin{array}{l}\text { The strategy envisages the development of the } \\
\text { company due to qualitative changes in the } \\
\text { elements of the innovation process. The } \\
\text { strategy has a quite significant impact on the } \\
\text { production process. This is accompanied by the } \\
\text { formation of organizational structures. The } \\
\text { strategy is aimed at standard mass production. } \\
\text { The company is characterized by technological } \\
\text { borrowing and acquisition of technologies } \\
\text { related to the improvement of the developed } \\
\text { assortment. }\end{array}$ \\
\hline 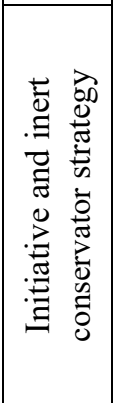 & $\begin{array}{l}\text { The strategy envisages the development of the } \\
\text { company due to quantitative and qualitative } \\
\text { changes in the elements of the innovation } \\
\text { process. There is not always an impact on the } \\
\text { production process and organizational } \\
\text { structure. The strategy is aimed at standard } \\
\text { mass production. The company is characterized } \\
\text { by the modernization of technological } \\
\text { processes related to the improvement of the } \\
\text { developed assortment. }\end{array}$ \\
\hline 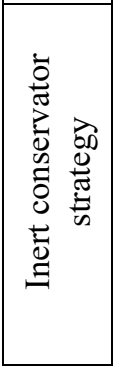 & $\begin{array}{l}\text { The strategy envisages the development of the } \\
\text { company due to quantitative changes in the } \\
\text { elements of the innovation process. There is } \\
\text { not always an impact on the production process } \\
\text { and organizational structure. The strategy is } \\
\text { aimed at standard mass production. The } \\
\text { company is characterized by the modernization } \\
\text { of technological processes, a slight } \\
\text { improvement of the developed assortment. }\end{array}$ \\
\hline
\end{tabular}

Source: Formed by authors based on [3], [19]

Each strategy for the company's innovative development mirrors a certain set of criteria. The importance attached to the criteria for choosing a company's innovative development is demonstrated by the level and quality of management in the company. In order for companies to remain competitive, they will need to move towards greater efficiency risks management and production, logistics and marketing. 
SoftServe was selected to approve the proposed methodology for choosing the strategy of innovative development. SoftServe performs the complete development and production cycle from sourcing finance for ideas, research and development to production and sale of innovative products.

Expert method for determining the weight of indicators has been used. The fifteen managers from the marketing and investment, investment, planning department have been invited to take part as independent experts. The survey was carried out by «Rating» in 2018 [24].

An expert evaluation of the weight of indicators to calculate the integral indicator of the level of innovation activity and innovation capability is shown in Figure 4.

\begin{tabular}{|l|l|c|}
\hline $\begin{array}{c}\text { Direction of } \\
\text { research }\end{array}$ & \multicolumn{1}{|c|}{ Indicators } & $\begin{array}{c}\text { Weight of the } \\
\text { indicator }\end{array}$ \\
\hline $\begin{array}{l}\text { Assessing the } \\
\text { level of } \\
\text { innovation } \\
\text { activity }\end{array}$ & Innovation expenditure & 0,31 \\
\cline { 2 - 3 } & Innovation outcomes & 0,35 \\
\cline { 2 - 3 } & Pace of innovation & 0,34 \\
\hline \multirow{4}{*}{$\begin{array}{l}\text { Assessing the } \\
\text { level of } \\
\text { innovative } \\
\text { capability }\end{array}$} & $\begin{array}{l}\text { Production and } \\
\text { technological capability }\end{array}$ & 0,13 \\
\cline { 2 - 3 } & Company staff & 0,15 \\
\cline { 2 - 3 } & Investments & 0,14 \\
\cline { 2 - 3 } & Scientific and technical & 0,15 \\
\cline { 2 - 3 } & Marketing & 0,13 \\
\cline { 2 - 3 } & Innovative projects risk & 0,14 \\
\cline { 2 - 3 } & Management & 0,16 \\
\hline
\end{tabular}

Figure 4. Expert evaluation of the weight of indicators to calculate the integral indicator of the level of innovation activity and innovation capability

Source: Formed by authors based on [24]

The results of assessing the level of the innovative activity of SoftServe in comparison with the base year 2005 are shown in Figure 5. In 2005, the company demonstrated the highest innovation performance. The obtained value indicates a high level of the innovation activity. The value of the integral indicator received $(0,9795)$ illustrates a high level of innovation activity.

\begin{tabular}{|c|c|c|}
\hline Groups of indicators & Indicators & Value \\
\hline \multirow{5}{*}{ Innovation expenditure } & $C_{R D} / C_{R D 0}$ & 0,9581 \\
\cline { 2 - 3 } & $C_{I} / C_{I 0}$ & 0,8184 \\
\cline { 2 - 3 } & $C_{P} / C_{P 0}$ & 1,0185 \\
\cline { 2 - 3 } & $C_{M} / C_{M 0}$ & 0,9936 \\
\cline { 2 - 3 } & $C_{P P} / C_{P P 0}$ & 0,9897 \\
\hline \multirow{5}{*}{ Innovation outcomes } & $N_{T P} / N_{T P 0}$ & 1,0713 \\
\cline { 2 - 3 } & $N_{I} / N_{I 0}$ & 1,0638 \\
\cline { 2 - 3 } & $N_{P} / N_{P 0}$ & 0,9943 \\
\cline { 2 - 3 } & $N_{C I} / N_{C I 0}$ & 1,0321 \\
\cline { 2 - 3 } & $N_{P P} / N_{P P 0}$ & 1,0147 \\
\hline
\end{tabular}

\begin{tabular}{|c|c|c|}
\hline \multirow{4}{*}{ Pace of innovation } & $D_{R D} / D_{R D 0}$ & 0,8966 \\
\cline { 2 - 3 } & $D_{I} / D_{I 0}$ & 0,9767 \\
\cline { 2 - 3 } & $D_{P} / D_{P 0}$ & 0,9367 \\
\cline { 2 - 3 } & $D_{M} / D_{M 0}$ & 0,9461 \\
\hline & $D_{P P} / D_{P P 0}$ & 0,9622 \\
\hline \multicolumn{2}{|c|}{ Integral indicator } & $\mathbf{0 , 9 7 9 5}$ \\
\hline
\end{tabular}

Figure 5. Assessment of the innovative activity level of SoftServe

Source: Formed by authors

The results of assessing the level of innovative capability of the company in comparison with the base year 2005 are shown in Figure 6.

\begin{tabular}{|c|c|c|c|}
\hline Indicator groups & Indicator & Value & $\begin{array}{c}\text { Value by } \\
\text { group }\end{array}$ \\
\hline \multirow{4}{*}{$\begin{array}{l}\text { Production and } \\
\text { technological } \\
\text { capability }\end{array}$} & $K_{e c} / K_{e c 0}$ & 0,923 & \multirow{4}{*}{0,096} \\
\hline & $K_{e m} / K_{e m 0}$ & 0,933 & \\
\hline & $K_{i n} / K_{i n 0}$ & 0,885 & \\
\hline & $F$ & 0,965 & \\
\hline \multirow{4}{*}{ Company staff } & $S_{e} / S_{e 0}$ & 0,892 & \multirow{4}{*}{0,141} \\
\hline & $S_{s t} / S_{s t 0}$ & 0,971 & \\
\hline & $S_{e c} / S_{e c 0}$ & 0,967 & \\
\hline & $S_{e s} / S_{e s 0}$ & 0,971 & \\
\hline \multirow{6}{*}{ Investments } & $I_{d p} / I_{d p 0}$ & 0,955 & \multirow{6}{*}{0,122} \\
\hline & $I_{i p} / I_{i p 0}$ & 0,952 & \\
\hline & $I_{p s} / I_{p s 0}$ & 0,891 & \\
\hline & $R_{l} / 1$ & 0,97 & \\
\hline & $R_{a} / 0,5$ & 0,499 & \\
\hline & $R O A / R_{d}$ & 0,951 & \\
\hline \multirow[b]{2}{*}{$\begin{array}{l}\text { Scientific and } \\
\text { technical } \\
\text { capability }\end{array}$} & $C A_{s l} / C A_{s l 0}$ & 0,929 & \multirow[b]{2}{*}{0,061} \\
\hline & $\begin{array}{l}C A_{\text {mip }} / \\
C A_{\text {mip } 0}\end{array}$ & 0,811 & \\
\hline \multirow{3}{*}{ Marketing } & $V_{p s} / V_{p s 0}$ & 0,968 & \multirow{3}{*}{0,121} \\
\hline & $C E I / C E I_{0}$ & 0,888 & \\
\hline & $P s / P s_{0}$ & 0,925 & \\
\hline \multirow{2}{*}{$\begin{array}{l}\text { Innovative } \\
\text { projects risk }\end{array}$} & $R c p / R c p_{0}$ & 0,962 & \multirow{2}{*}{0,128} \\
\hline & $R p i / R p i_{0}$ & 0,972 & \\
\hline \multirow{3}{*}{ Management } & $M_{e} / M_{e 0}$ & 0,901 & \multirow{3}{*}{0,149} \\
\hline & $M_{n e} / M_{n e 0}$ & 0,913 & \\
\hline & $M_{c e} / M_{c e 0}$ & 0,978 & \\
\hline \multicolumn{3}{|c|}{ Integral indicator } & 0,819 \\
\hline
\end{tabular}

Figure 6. Assessment of the innovative capability level of SoftServe

Source: Formed by authors 
The indicators were used to assess the achievements of the company based on high complexity surveys and polls [24]. The value of integral indicator received $(0,819)$ illustrates below the average level of innovative capability. The value of integral indicator received according to the scale, as summarized in Figures 5, 6 reflects the choice of the initiative alternator strategy.

\section{Discussion}

The company is characterized by the innovative development of the company due to the qualitative changes in the elements of the innovation process and the maximum utilization of the existing capabilities. The company has a complete production process. This is accompanied by the formation of organizational structures, the creation of completely new ideas, models, technologies, products. The company motivates the staff as much as possible in overcoming current challenges, creation of innovations, support, implementation, transfer, and marketing of innovations.

Thus, as we can see, an ongoing innovation advantage is possible if the organization focus is to build organizational capabilities along with adequate adaptations to mindsets, skills, behaviors and decision structures in an environment of global resources, flexible, efficient, resilient business processes and focused analytics [17]. Innovation requires both technical and market capabilities; requires hold over the complementary assets if necessary, as well as the ability to protect its innovation through patents, copyrights, trademarks, trade secrets [1]. For innovations to be competitive, firms need to be concerned about quickness to market, shortened product development times, constant upgrading that includes flexibility in R\&D processes and technological leapfrogging [8]. Proactive market orientation is needed for innovations to succeed [14].

In accordance with the strategy of the innovative development of Ukraine, companies should make a full assessment of the innovative capability and the innovative activity. The company's response to the innovative development has led many to a good assessment of the capability of innovative efforts and the government agencies to respond to new developments, innovations.
The experience with the current assessment demonstrates that the process of evaluating innovative aspects of work is sorely lacking in the majority of companies. But the timing of an assessment can be critical and calls for a clear assessment of the innovative capability and the innovative activity of the company to ensure that the weight of any operation is appropriate.

\section{Conclusion}

The conducted research of approaches to the formation of strategy for the company's innovative development allowed us to find strategy by two components. The first component includes the integral indicator that characterizes the main aspects of the company's innovation activities by innovation expenditure, innovation outcomes and the pace of innovation. The second component includes the integral indicator that characterizes the innovative capability of the company according to the internal and external groups.

We have developed the methodical approach to the assessment of level: company's innovation activities, innovative capability. This approach offers integral indicators formation of the strategy that takes into account the innovation development of the company in two areas.

This approach is based on the construction of the scale of the choice within a strategy for the company's innovative development, and allows identifying types of strategies. Assessment of the integral indicators (level of company's innovation activities, level of innovative capability) of the provided company allows asserting whether the strategy will contribute to the innovative growth of the enterprise. It is important to focus on enhancing all the components in order to improve the company's performance and innovation. The strategy of the company does not need to be perceived only as a source of the costs. Calculation results are a measure of resource efficiencies and encourage the business to develop forward-looking innovation strategic behavior. This is essentially a question of forming measures that can drive different kinds of the innovation, such as investment incentives, activation of creative activity of employees.

The conducted research is the basis for the formation of innovative strategies and programs of the enterprise development. The proposed methodology can be adapted to enterprises of all types of the economic activity and ownership. 


\section{References}

[1]. Afuah, A. (2003). Innovation Management, N. Y.:Oxford University Press.

[2]. Annex, X. V. I. I. (2014). Association Agreement between the European Union and its Member States, of the one part, and Ukraine, of the other part. Official Journal of the European Union L, 161(29.5).

[3]. Białoń, L. (1999). Typologia innowacyjnych strategii rozwoju,[w:] Innowacje techniczne i zmiany strukturalne w procesie transformacji polskiej gospodarki, red. AH Jasiński, M. Kruk, Uniwersytet w Biatymstoku, Biatystok.

[4]. Dachyar, M., \& Tjiptadi, A. T. (2019, August). Original Equipment Manufacturer (OEM) Site Selection of Traditional Medicine Companies in Indonesia using Analytic Hierarchy Process (AHP) Method. In IOP Conference Series: Materials Science and Engineering (Vol. 598, No. 1, p. 012090). IOP Publishing.

[5]. Goldstein, G. Ya. (2012). Strategic innovation management: trends, technologies and practice. Taganrog: TRTU.

[6]. Harrington, J. H. (1990). Quality management in corporate America: Abbr. per. from English./Auto. introd. Art. and scientific. Ed. LA Konareva. Moscow: Economics.

[7]. Hittmár, ড̌., Varmus, M., \& Lendel, V. (2014). Proposal of model for effective implementation of innovation strategy to business. Procedia-Social and Behavioral Sciences, 109, 1194-1198.

[8]. Hoonsopon, D., \& Guntalee, R. (2012). The impact of organizational capabilities on the development of radical and incremental product innovation and product innovation performance. Journal of Managerial Issues, 26(3), 250-276

[9]. Illiashenko, N.S. \& Shypulina, Y.S. (2018). Criteria of evaluation and selection of strategic directions of scientific and technological development of the enterprise, Odesa National University Herald. Series Economy, 23, 8 (73), 83-87. (in Ukrainian).

[10]. Jorion, P. (2010). Financial Risk Manager Handbook: FRM Part I (Vol. 625). John Wiley \& Sons.

[11]. Lendel, V., Hittmár, Š., \& Siantová, E. (2015, August). Identification of the Main Problems in the Management of Innovation Processes and the Draft of Appropriate Recommendations. In International Conference on Knowledge Management in Organizations (pp. 221-232). Springer, Cham.
[12]. Lendel, V., Moravčíková, D., \& Latka, M. (2017). Organizing innovation activities in company. Procedia engineering, 192, 615-620.

[13]. Nagano, M. S., Stefanovitz, J. P., \& Vick, T. E. (2014). Innovation management processes, their internal organizational elements and contextual factors: An investigation in Brazil. Journal of Engineering and Technology Management, 33, 63-92.

[14]. Narver, J. C., Slater, S. F., \& MacLachlan, D. L. (2004). Responsive and proactive market orientation and new-product success. Journal of product innovation management, 21(5), 334-347.

[15]. O'Connor, G. C., Ravichandran, T., \& Robeson, D. (2008). Risk management through learning: Management practices for radical innovation success. The Journal of High Technology Management Research, 19(1), 70-82.

[16]. Zartha, J. W., \& Hernández, R. (2013). Aplicación de una Metodología de Gestión de Innovación y Tecnología en una Empresa de Alimentos en Armenia-Colombia. GPT Gest. Pers. Tecnol, 18, 5465.

[17]. Prahalad, C. K., \& Krishnan, M. S. (2008). The new age of innovation. McGraw-Hill Professional Publishing.

[18]. Prokopyeva, A. V., \& Nechaev, A. S. (2013). Key features of risks of company innovative activities. Middle East Journal of Scientific Research, 17(2), 233-236.

[19]. Stadnyk, V. V., \& Yokhna, M. A. (2006). Innovatsiinyi menedzhment. Kyiv: Akademvydav.

[20]. Sitek, M. (2019). Barriers of Innovation Activity as Risk Factors on the Real Estate Market, IBIMA Business Review, p. 12.

[21]. Yang, J. (2012). Innovation capability and corporate growth: An empirical investigation in China. Journal of Engineering and Technology Management, 29(1), 34-46.

[22]. Yurynets, Z., Bayda, B., \& Petruch, O. (2015). Country's economic competitiveness increasing within innovation component. Economic magazine -XXI, (910), 32-35.

[23]. Yurynets, Z., Yurynets, R., \& Gutor, T. (2017). Game theory model for the development of optimal strategy towards innovative products manufacturing at the enterprise. Problems and perspectives in management, (15, Iss. 3 (contin. 1)), 285-294.

[24]. Zakharchyn, G., \& Kosmina Y. (2018). Intellectual culture in the knowledge management system. Black sea economic studies, 27, 129-133 (in Ukrainian). 